Original Article

\title{
Influence of Pilates Mat and Apparatus Exercises on Pain and Balance of Businesswomen with Chronic Low Back Pain
}

\author{
Chae-Woo Lee, PT, MS ${ }^{1)}$, Ju Hyun, PT, MS ${ }^{1 *}$, Seong Gil Kim, PT, MS ${ }^{1)}$ \\ 1) Department of Rehabilitation Science, Graduate School, Daegu University: 15 Jilyang, \\ Gyeongsan-si, Gyeongbuk 712-714, Republic of Korea
}

\begin{abstract}
Purpose] The purpose of this study was to examine the influence of mat Pilates and apparatus Pilates on pain and static balance of businesswomen with chronic back pain. [Subjects and Methods] Participants were randomly allocated to Pilates mat exercises (PME) or Pilates apparatus exercise (PAE), and performed the appropriate Pilates exercises 3 days per week for 8 weeks. In order to measure the improvement in the participants' static balance ability as a result of the exercise, the sway length and sway velocity of the subjects were measured before and after the experiment while the subjects stood on a Balance Performance Monitor (BPM) facing the front wall for 30 seconds with their eyes open. The visual analogue scale (VAS) was used to measure the degree of pain. [Results] The VAS score, sway length, and sway velocity of both groups decreased significantly after the experiment, but the PME group showed a greater decrease than the PAE group. [Conclusion] PME showed greater improvement in pain level and balance compared with PAE in this research. Since the subjects of this study were patients with low back pain, PME is assumed to have been more suitable and effective because it uses body weight to strengthen core muscles rather than heavier apparatuses as in PAE.

Key words: Pilates mat exercise, Pilates apparatus exercises, LBP
\end{abstract}

(This article was submitted Aug. 29, 2013, and was accepted Oct 16, 2013)

\section{INTRODUCTION}

Low back pain (LBP) is one of the most common complaints in today's society and is the main reason why adults younger than 45 years old experience discomfort ${ }^{1)}$. Debilitating back pain that continues for more than 3 months is considered chronic ${ }^{2}$.

LBP occurs when coordination and stabilization of the trunk muscles are weak ${ }^{3)}$. LBP negatively affects the trunk, including its strength and endurance; it brings about abnormal changes in the neuromuscular mechanism that influences trunk stabilization and efficiency when exercising ${ }^{4)}$. This negative influence on spine stabilization is in response to muscle stability, mobility, and length ${ }^{5)}$ and affects balance, which is why the purpose of stabilization exercises for LBP patients is to improve balance. Static balance, which is a part of overall balance, is the ability to maintain the center of gravity on a fixed base of support ${ }^{6)}$.

The central nervous system makes use of proprioceptive information of the muscles, joints, and skin receptors for general movement and static balance, enabling the body to exercise efficiently ${ }^{7}$. Of the many exercise therapies

*Corresponding author. Ju Hyun (E-mail: julight3@naver.

com)

(C)2014 The Society of Physical Therapy Science. Published by IPEC Inc. This is an open-access article distributed under the terms of the Creative Commons Attribution Non-Commercial No Derivatives (by-ncnd) License $<$ http://creativecommons.org/licenses/by-nc-nd/3.0/> for chronic back pain patients, stabilization exercises that strengthen abdominal and pelvic muscles for improving spine stabilization and posture maintenance ${ }^{8)}$ are widely used. As a means to stabilize the trunk, Pilates exercises, which are centered around the core muscles, are popular among LBP patients ${ }^{9}$.

The Pilates method can be categorized into mat Pilates and apparatus Pilates; the latter is a type of resistance exercise that uses springs and pulleys from apparatuses, such as the reformer and Cadillac ${ }^{10)}$.

This study examined the influence of mat Pilates and apparatus Pilates on pain and static balance of businesswomen with chronic back pain.

\section{SUBJECTS AND METHODS}

The subjects of this study were 40 businesswomen who exercised at K Sports Center and H Sports Center in Busan, Korea, and had chronic back pain even though they had no prior orthopedic illness other than cardiovascular symptoms and LBP. All subjects were provided with information on the research before they consented to participate (Table 1). All included patients understood the purpose of this study and provided written informed consent prior to their participation in the study in accordance with the ethical standards of the Declaration of Helsinki.

Participants were randomly allocated to Pilates mat exercises (PME) or Pilates apparatus exercises (PAE), and they performed the appropriate Pilates exercises 3 days per 
week for 8 weeks. The exercise programs were 50 -minutes long - 10 minutes of warm up, 30 minutes of the main exercises, and 10 minutes of cool down-and consisted of exercises that were relevant to LBP therapy (Table 2). In order to measure the improvement in the participants' static balance ability as a result of the exercising, sway length and sway velocity of the subjects were measured before and after the experiment while the subjects stood on a Balance Performance Monitor (BPM: software version 5.3, SMS Healthcare Inc., UK) facing the front wall for 30 seconds with their eyes open. The visual analogue scale (VAS) was used to measure the degree of pain. All measurement results were expressed as the mean \pm standard deviation.

SPSS for Windows (version 18.0) was used to analyze the data. Paired t-tests were used to examine pre- and postintervention differences, and independent t-tests were used to examine differences between the groups. The statistical significance level was set to $\alpha=0.05$.

\section{RESULTS}

The VAS score, sway length, and sway velocity of both groups decreased significantly after the experiment $(p<0.05)$, but the PME group showed a greater decrease than the PAE group $(\mathrm{p}<0.05)$ (Table 3$)$.

\section{DISCUSSION}

LBP may occur if inner core muscles (transversus abdominis muscle, floor muscle, diaphragm, multifidus muscles) are weakened or disabled ${ }^{11)}$. Biering-Sorensen ${ }^{12)}$ asserted that strengthening of all body muscles and maintenance of balance can prevent reoccurrence of LBP. Exercises that strengthen abdominal muscles, pelvic muscles, and spine stabilization are widely used for patients with chronic

Table 1. General characteristics of subjects

\begin{tabular}{lrr}
\hline & \multicolumn{1}{c}{ PME } & \multicolumn{1}{c}{ PAE } \\
\hline Age (years) & $34.0 \pm 3.3$ & $34.4 \pm 3.1$ \\
Height (cm) & $162.5 \pm 2.9$ & $162.8 \pm 3.8$ \\
Weight $(\mathrm{kg})$ & $55.8 \pm 4.0$ & $56.3 \pm 3.9$ \\
\hline Mean \pm SD & &
\end{tabular}

back pain ${ }^{8)}$. Of all the various exercise methods, Pilates therapy is the most popular because it has the least degree of possible injury and can easily be practiced by anyone ${ }^{13)}$.

LBP causes the patient's overall activity to decrease, and long-term inactivity of the body will weaken muscular strength and cause amyotrophia ${ }^{14)}$. The decreased pain level that was observed in this research showed that Pilates exercises prevent amyotrophia by lessening the patient's pain, hence preventing inactivity. Although both PME and PAE resulted in a significant decrease in pain level in the participants, the improvement from PME was greater.

LBP patients tend to have weak balance because normal sensory information to muscular and sensory organs becomes unnatural, thus obstructing the ability to control balance ${ }^{15)}$ and weakening waist extensor muscles ${ }^{16)}$. In the present study, both groups showed decreased sway length and sway velocity, but the PME group had a greater decrease than the PAE group. The results of this experiment agree with the findings of previous studies that showed isometric contraction - maintaining the last range of muscular activity for more than 30 seconds - during Pilates exercises increases balance control and strengthens trunk stabilization ${ }^{17)}$, increases balance ability and posture stabilization of healthy adults ${ }^{18)}$, and strengthens balance control muscles by improving body alignment and increasing static balance ability of LBP patients ${ }^{19}$.

PME showed greater improvement in pain level and balance compared with PAE in this research. Since the sub-

Table 3. Comparison of measurement values before and after the experiment

\begin{tabular}{llcc}
\hline Variable & Group & Before & After \\
\hline Visual analogue & PME & $5.1 \pm 1.1$ & $2.8 \pm 0.9^{\mathrm{ab}}$ \\
scale (score) & PAE & $5.2 \pm 0.8$ & $3.4 \pm 0.9^{\mathrm{a}}$ \\
Sway length & PME & $221.9 \pm 15.7$ & $132.6 \pm 11.9^{\mathrm{ab}}$ \\
$(\mathrm{mm})$ & PAE & $220.9 \pm 18.7$ & $151.9 \pm 11.4^{\mathrm{a}}$ \\
Sway velocity & PME & $30.3 \pm 5.9$ & $19.6 \pm 5.6^{\mathrm{ab}}$ \\
$(\mathrm{mm} / \mathrm{s})$ & PAE & $30.2 \pm 6.9$ & $23.6 \pm 5.5^{\mathrm{a}}$ \\
\hline
\end{tabular}

PME, Pilates mat exercise; PAE: Pilates apparatus exercise, ${ }^{a}$ Significant difference between before and after and after the experiment, ${ }^{\mathrm{b}}$ Significant difference between PME and PAE after the experiment

Table 2. Explanation of exercise program

\begin{tabular}{|c|c|}
\hline Group & \\
\hline PME & $\begin{array}{l}\text { Breathing: } 5 \text { reps. Imprint \& releas: } 3 \text { reps } \times 2 \text { set. Supine spinal: } 3 \text { reps } \times 2 \text { sets, Arm circles: } 3 \text { reps } \times 3 \text { sets. Knee } \\
\text { over knee twist stretch: } 5 \text { reps. Pelvic peel and hinge: } 5 \text { reps } \times 2 \text { sets. Spine spinal with arms crossed: } 5 \text { reps } \times 3 \text { sets. } \\
\text { Seated hip stretch: } 2 \text { reps. Hundred: } 10 \text { reps } \times 1 \text { sets. Roll up \& Roll down: } 5 \text { reps } \times 2 \text { sets. Swimming: } 10 \text { reps } \times 3 \\
\text { sets. Side lying: } 5 \text { reps } \times 2 \text { sets. side kick: } 5 \text { reps } \times 2 \text { sets. Single leg circle: } 5 \text { reps } \times 2 \text { sets. Mermaid: } 5 \text { reps } \times 2 \text { sets. } \\
\text { Roll Over: } 3 \text { reps. Spine forward: } 2 \text { reps. Child position: } 2 \text { reps. Breathing: } 5 \text { reps. }\end{array}$ \\
\hline PAE & $\begin{array}{l}\text { Breathing: } 5 \text { reps. Hamstring stretch: standing tall position, straight legs ( } 6 \text { reps } \times 2 \text { sets). Mermaid: sit tall, one hand } \\
\text { on foot bar }\left(5 \text { reps } \times 2 \text { sets). Arms up and down: pelvis neutral, hip flexion } 90^{\circ} \text { holding hand strap }(5 \text { reps } \times 2 \text { sets). }\right. \\
\text { Arms up and pull down: supine position, straight legs, pelvis neutral }(5 \text { reps } \times 2 \text { sets). Footwork toes and heels: supine, } \\
\text { pelvis neutral ( } 5 \text { reps } \times 2 \text { sets). Sit ups: supine, straight legs ( } 10 \text { reps } \times 2 \text { sets). Gluteus and trunk raises: neutral pelvis, } \\
\text { legs above push bar }(5 \text { reps } \times 3 \text { sets). One legs above barrel ( } 4 \text { reps } \times 3 \text { sets). Leg stretch: standing, Breathing: } 5 \text { reps. }\end{array}$ \\
\hline
\end{tabular}

PME, Pilates mat exercise; PAE, Pilates apparatus exercise 
jects of this study were LBP patients, PME is assumed to have been more suitable and effective because it uses body weight to strengthen core muscles rather than heavier apparatuses as in PAE.

In conclusion, Pilates exercises can provide effective help for chronic back pain patients. The limitations of this study include no post-training monitoring to determine how long the results last and subjective measurement of pain since, only the VAS was used. Considering these limitations, future studies should be performed using a variety of different methods of applying Pilates exercises to LBP patients.

\section{REFERENCES}

1) da Fonseca JL, Magini M, de Freitas TH: Laboratory gait analysis in patients with low back pain before and after a Pilates intervention. J Sport Rehabil, 2009, 18: 269-282. [Medline]

2) Donzelli S, Di Domenica E, Cova AM, et al.: Two different techniques in the rehabilitation treatment of low back pain: a randomized controlled trial. Eura Medicophys, 2006, 42: 205-210. [Medline]

3) Gladwell V, Head S, Haggar M, et al.: Does a program of Pilates improve chronic non-specific low back pain? J Sport Rehabil, 2006, 15: 338-350.

4) Rydeard R, Leger A, Smith D: Pilates-based therapeutic exercise: effect on subjects with nonspecific chronic low back pain and functional disability: a randomized controlled trial. J Orthop Sports Phys Ther, 2006, 36 : 472-484. [Medline] [CrossRef]

5) Comerford MJ, Mottram SL: Functional stability retraining: principles and strategies for managing mechanical dysfunction. Man Ther, 2001, 6: 3-14. [Medline] [CrossRef]

6) Ragnarsdottir M: The concept of balance. Phys Ther, 1996, 82: 368-375.

7) Nurse MA, Nigg BM: The effect of change in foot sensation on plantar pressure and muscle activity. Clin Biomech (Bristol, Avon), 2001, 16: 719
727. [Medline] [CrossRef]

8) Desai I, Marshall PW: Acute effect of labile surfaces during core stability exercises in people with and without low back pain. J Electromyogr Kinesiol, 2010, 20: 1155-1162. [Medline] [CrossRef]

9) Culligan PJ, Scherer J, Dyer K, et al.: A randomized clinical trial comparing pelvic floor muscle training to a Pilates exercise program for improving pelvic muscle strength. Int Urogynecol J, 2010, 21: 401-408. [Medline] [CrossRef]

10) Silva AC, Mannrich G: Pilates na reabilitação: uma revisão sistemática. Rev Fisioter Mov, 2009, 22: 449-455.

11) Hodges PW, Richarson CA: Inefficient muscular stabilization of the lumbar spine associated with low back pain. Spine, 1996, 21: 2640-2650. [Medline] [CrossRef]

12) Biering-Sørensen F: A prospective study of low back pain in a general population. I. Occurrence, recurrence, aetiology. Scand J Rehabil Med, 1983, 15: 71-79. [Medline]

13) Decker MJ, Hintermeister RA, Faber KJ: Serratus anterior muslce activity during selected rehabilitation exercise. Am J Sports Med, 1999, 27: 784-791. [Medline]

14) Cooper RG, St Clair Fordes W, Jayson MI: Radiographic demonstration of paraspinal muscle wasting in patient with chronic low back pain. Br J Rheumatol, 1992, 31: 1247-1253.

15) Luoto S, Aalto H, Taimela S, et al.: One-Footed and externally disturbed two-footed postural control in patients with chronic low back pain and healthy control subjects. Spine, 1998, 23: 2081-2089. [Medline] [CrossRef]

16) Hodges PW, Richardson CA: Contraction of the muscles associated with movement of the lower limb. Phys Ther, 1997, 77: 132-142. [Medline]

17) Sekendiz B, Altun O, Korkusuz F, et al.: Effects of Pilates exercise on trunk strength, endurance and flexibility in sedentary adult females. J Bodyw Mov Ther, 2007, 11: 318-326. [CrossRef]

18) Johnson EG, Larsen A, Ozawa H, et al.: The effects of Pilates-based exercise on dynamic balance in healthy adults. J Bodyw Mov Ther, 2007, 11: 238-242. [CrossRef]

19) Carmeli E, Shmuel BC, Meir L: Five clinical tests to assess balance following ball exercise and treadmill training in adult persons with intellectual disability. J Gerontol Med Sci, 2003, 58: 767-772. [CrossRef] 